\title{
Preliminary Discussion on the Cultural Communication of Shui Nationality in Yunnan under the Perspective of New Media
}

\author{
Jingjing Wang \\ School of Music and Dance, Qujing Normal University, Qujing 655011, China
}

Keywords: Shui Nationality in Yunnan, culture, summary, change

\begin{abstract}
Shui Nationality is a small branch in the large system of fifty-six nationalities in China, and in the national development and growth process, it gradually forms the cultural traditions with its own national characteristics and geographical characteristics, which injects vigor and vitality for the development of Chinese culture. In this paper, it reviews the current research situation of Shui Nationality culture, including the origin of Shui Nationality, folk culture, national sports culture, swallowing mouth culture, and has a preliminary discussion on the cultural communication and influencing factors of Shui Nationality under the perspective of new media.
\end{abstract}

\section{Introduction}

Shui Nationality is one of the minorities with a long history and rich culture, which has its own language (Shui language) and characters (Shui characters) ${ }^{[1]}$. It has a population of about 350,000 people (calculated in 1990), whose people mainly live in the places in the south of Miaoling mountains in the southeast of Yunnan-Guizhou Plateau and in the upstream of Duliu River and Longjiang, such as Libo, Dushan, Duyun, Danzhai, Leishan, Rongjiang and Congjiang, and rarely live in the counties in the west of the Guangxi Zhuang Autonomous Region such as Nandan, Hechi, and Yishan, where there are dense forests suitable for the development of agricultural and forestry, for the people of Shui Nationality are principally engaged in agriculture and rice cultivation. In recent years, the research on the Shui Nationality culture has achieved fruitful results, so on the basis of elaborating and interpreting the rich and excellent cultural phenomenon of Shui Nationality, this paper has a preliminary discussion on the cultural communication and influencing factors of Shui Nationality.

\section{The origin of Shui Nationality and twice migration in history.}

About the origin of Shui Nationality, there are three focuses of contention generally in civil society and academia: first is the descendant of Yin People, second is the origin of Baiyue nationality, and third is moving from South of the Yangtze River. Before Qin and Han dynasty, there was a large population inhabited in the south of the Five Ridge and the southeast coastal areas. Due to the different surnames in the ethnic group, so it was called "Baiyue" tribe by historians. In Qin and Han dynasty, due to the different living places, Baiyue ethnic group in Zhejiang area was called "Eastern Yue", in the area from southern Zhejiang to northern Fujian was called "Min Yue", and in the bordering land of northern Guangxi and southern Guizhou was called "Luo Yue". The ancestors of Shui Nationality were a branch of "Luo Yue". In history, Shui Nationality once had two great migrations, first was Yin people moved to south to integrate to Baiyue ethnic group after the demise of the Shang Dynasty; second was that after the Qin Dynasty unified China, it once sent armed force to suppress the south of the Five Ridges, so the ancestors of Shui Nationality were separated from Baiyue and lived in the upstream area of Longjiang and Duliu River. The Shui books with cultural characteristics of Shui Nationality are the relicts of Xia and Shang culture and the spiritual sustenance of Shui Nationality.

\section{Folk holidays of Shui Nationality}

Folk custom is the life style and customs in the folk passed on from generation to generation, which is originated from the needs of human social group live and continuously formed, expanded 
and evolved in every nation, time and region to gradually become the folk customs conventionalized and commonly obeyed by the people of this nationality. This unique ethnic lifestyle and custom with regionality and inheritance enriches people's spiritual and cultural life, at the same time enhances the national cohesion [2], and becomes the time and bridge for the national development and expansion.

In the long process of historical development, Shui Nationality created a rich and colorful folk festival culture. There are two types of festivals for Shui Nationality, one is the unique traditional festival and the other is the festival influenced by other ethnic nationalities lived nearby or miscellaneously such as Han, Miao and Dong, etc. Its unique and large traditional festivals are Jiemao, Jieduan, Suning Xi Festival, Jingxia Festival, and "Double March" (Sacrifice to Dragon Pool), Double Sixth (Sacrifice to God of Land), June Twenty Second (also called "Sacrifice to God of Mountains"). Other festivals affected by other ethnic groups are Dragon Boat Festival, Tomb Sweeping Day, Mid-July Days, Double Sixth to sacrifice to God of Land, etc [3]. Sacrifice to Dragon Pool, Sacrifice to God of Land, and Sacrifice to God of Mountains are now the three folk festivals with the most festival atmosphere except for the Chinese New Year in Wuzhai of Shui Nationality.

Jiemao and Jieduan are the biggest festival in Shui Nationality, which are equivalent to the Chinese New Year of Han Nationality in the hearts of Shui Nationality. In different regions of Shui Nationality, they will choose to celebrate Mao Festival or Duan Festival without celebrating both. Shui people live in Jiuxian area of Sandu County and some places in Libo County will celebrate "Mao Festival", but the Shui people live in Duyun, Dushan will celebrate "Duan Festival" in Lunar September every year (i.e. From January to February in the calendar of Shui Nationality).

In Shui language, "Mao Festival" is called "Jiemao", which is usually held in the Mao day of the lunar May and June (i.e. September and October in Shui calendar) after finishing transplant rice seedlings, and people will take turns to celebrate the festival in batches. When celebrate the Mao Festival, many regions still prevail the ancient customs such as catching Mao slope, young men and women singing in antiphonal style. The young men and women in Shui Nationality regard singing in antiphonal style as an important form of the social activities between men and women. Whether the people of Shui Nationality or people in every age from other villages or neighbor counties who do not celebrate Mao Festival, they will come to participate in this event. If both men and women in singing in antiphonal style find their bosom friends, they can select a good time to get married, and they will be blessed by families. Therefore, the Mao Festival of Shui Nationality is also known as "ancient oriental Valentine's Day".

In Shui language, Duan Festival is called "Jieduan", which is a grand festival for Shui Nationality to pray for a good harvest. For the Duan Festival, it will continue for more than 50 days from the first batch to the final batch, and it is the major festival with the longest time, most celebrating times and most local and national characteristics in the world.

Suning Xi Festival is the Chou day in Lunar December (April in Shui calendar). In Shui Nationality, it is said that the "Mother Goddess" will send babies to the mortal world on that day, so it is also known as "Goddess Day", and people will carry out activities to sacrifice Mother Goddess on that day.

"Jingxia Festival” is also known as God Worship Day, because "Xia” in Shui language has the meaning of "God of Water". Jiuxian area in Sandu County and other neighbor areas will celebrate Jingxia Festival. On that day, people of Shui Nationality will get together and place the libation on the altar to pray for good weather and good harvest. The Time to celebrate Jingxia Festival is normally every two years, six years and the longest interval is 12 years once. So far, in Shui Nationality areas, they still keep the ancient customs of celebrating Suning Xi Festival and Jingxia Festival.

\section{Traditional sports culture of Shui Nationality}

In the long historical process, Shui Nationality created and developed a unique traditional sports culture, which was formed and accumulated through long practice and development in the unique 
environmental region and specific social life of this nationality, and was the important part of excellent traditional culture of Shui Nationality. The traditional sports activities of Shui Nationality is both related to the nationality's psychology, temperament, economy, cultural morality and social development, and combined with the living environment, festivals, customs, folk customs of Shui Nationality, which clearly shows the characteristics of the national culture of farming, and is an important part of the culture of Shui Nationality ${ }^{[4]}$.

The existing traditional sports events of Shui Nationality are more than $60^{[5]}$, and the traditional sports activities carried out in the national festivals and folk activities have always existed in the social life of Shui Nationality and never stopped ${ }^{[6]}$. According to the survey analysis, the traditional sports events of the "Wuzhai of Shui Nationality" in Yunnan Gugan Village which still can be seen are lion dance, dragon dance, bamboo dance, antiphonal singing, money sticks, and swallowing dance, etc. After the 1990s, the sports events transformed according to the local traditional social life such as swallowing dance and glutinous rice cake dance are still very active and have grate influences. Tongzibiao is a sports activity with the most local characteristics, which is produced in the production life and ritual culture of Shui people, and has the competitive value to keep physical and mental health ${ }^{[7]}$.

\section{Featured folk culture of Shui Nationality - Swallowing mouth}

Family in Wuzhai of Shui Nationality who lived in a compact community has hung a head with its eyebrows and stares in anger on the banner of the gate - swallowing mouth custom. In Shui Language, swallowing mouth pronounces "Ji Gen", which is the mascot for Shui people to drive devils and pray protections from "swallowing" gods. According to the folklore, in order to drive pestilence, suppress devils and remove evils, the Dragon King in Dragon Pool suddenly becomes the "swallowing" "fetish" with human head, dog ears, protruding eyes, wide nose, fangs, grin, loll and a sword in the mouth, and he can swallow evils and suppress devils to protect the luck and health of Shui people. Gugan Shui Nationality regards "swallowing mouth" as their faith, reflecting the fear of Shui people towards the Dragon King and the good wishes for people longing for the life with auspicious health, flourishing population, and bumper harvest. Based on the "swallowing mouth" in folklore, the folk artists create "swallowing mouth" dance culture. There are five chapters in the "swallowing mouth" dance: "Double Fishes Cove the Gourd", "Interweave the Heart into the Shuttle”, "Connecting Sisters and Brothers", “Auspicious Swallowing Mouth”, and "This Year is Still Sweet", reflecting the swallowing mouth come to mortal world to fight with the God of Plague and devils, swallow and suppress evils to create a scene of peacefulness in the mortal world [8]. With the popularization of science and technology education, the prototype of swallowing mouth dance - swallowing mouth and its swallowing mouth opening ceremony have disappeared in the Wuzhai of Shui Nationality and its surrounding villages of Shui Nationality.

\section{Folk music and dance of Shui Nationality}

Shui Nationality is a nationality is good at singing and dancing and the traditional dances of Shui Nationality are mainly bronze-drum dance, doujiao dance, and lusheng dance. Bronze-drum dance is known as "throw and press" in Shui language, and is also "jump bronze drum". Doujiao dance is also called "douniu dance", and the Shui language of lusheng dance called "shidao". These dances are generally preformed during the holiday season, sacrifice activities and funeral rites. Actors participate in the bronze-drum dance are mostly men, who bend elbows, jump squat, rotate and interlude with rough and strong movements followed with the rhythm of drums in the central square, showing the mental state of wildness, unconstraint, and high-spirited for the people of Shui Nationality. The folk music of Shui Nationality has a particular ethnic style and the folk music instruments are mainly bronze drums, large fur drums, lusheng, suona horn, huqin, and so on. The bronze drum is the traditional folk music instrument of Shui Nationality, which is divided into male drum and female drum and is commonly used in the show of festivals, worship, funeral or grand 
celebration activities. The folk music of Shui Nationality have various forms, including dual song, single song, stump song, tune song, and interrogate song.

\section{The existing problems in the cultural communication of Shui Nationality}

The ethnic culture of Shui Nationality is rich and colorful, showing the spiritual tradition of wisdom and unity in the long historical development process of Shui people. With the development of times and constant enrichment of people's material and cultural life, various folk customs of Shui Nationality are also gradually developed to be mature and become a cultural form with unique ethnic characteristics. But with the development of time and changes of production and lifestyle, and the acceleration of interaction with other ethnic cultures, the original ecological traditional culture of Shui Nationality has fundamentally changed. Many of the traditional folk and traditional culture have gradually been eliminated by history, and only some of the classic events regard as historical heritage to be tenaciously preserved. Firstly, the most important traditional sports event of Shui people - horse racing in Duan Festival has lost its original size and flavor, and many other ethnic groups have also participated in the horse racing in Duan Festival; while the traditional sports of Han Nationality, Buyi Nationality, Miao Nationality, Dong Nationality and Yao Nationality such as bullfighting, playing shuttlecock by hands, picking pole, paddling dragon boat, playing lion, and playing dragon are also generally carried out in this region, which have a significant impact on the traditional sports cultural activities of Shui Nationality; secondly, even though the traditional sports activities of Shui Nationality are various and rich, the activities nowadays able to continue to carry out are handful, and some events have been phased out, facing with the danger of losing and disappearing; thirdly, some events with ethnic characteristics are not well inherited and developed, and the protection, development and utilization are not enough; fourthly, for the social changes causing the difficult heritance of some events, their ethnic cultural characteristics are gradually disappearing and diluting, if we do not increase the protection, it will become a piece of memory can not reply permanently. For example, there are more than 50 traditional sports events for Wuzhai of Shui Nationality, but only more than 10 events have handed down; according to statistics, there are more than 20 kinds of boxing for Shui Nationality and more than 10 kinds of instruments. But now very few people carry out the competition of these events, and the people who can martial arts are very few and almost lost. Fifthly, the development of traditional sports culture of Shui Nationality is a great event of the whole nation, but currently these factors such are the shortage of funds, remote and poor location of some Shui Nationality, inconvenient transportation, weak infrastructure, relatively backward economy, and severe blocking of information severely restrict the healthy development of ethnic culture of Shui Nationality, while the inadequate funding situation is the main factor troubled the development of traditional sports of Shui Nationality [9]. "Swallowing mouth" dance is the most featured folk art of Shui Nationality, but the talent cultivation of "swallowing mouth" has not been paid enough attention. Therefore, how to make this ancient traditional activity maintain its characteristics has become a top priority to hand down from generation to generation in the area of Shui Nationality.

\section{Conclusion}

Shui Nationality is a nationality with a long historical cultural tradition, whose traditional culture reflects not only the long-term social development process of Shui Nationality, but also their lifestyle and ethnic customs, which has a profound historical and cultural value. Research results show that the excavation and systemization of the traditional culture of Shui Nationality are very important to keep its traditional cultural characteristics, and keep and develop its excellent cultural heritage. Studying the social historical value and its heritage strategy of the traditional sports culture of Shui Nationality in Yunnan Province has great significance for the integrity of its traditional sports culture, and better excavating and protecting the culture of Shui Nationality. But due to various restrictions such as the diversity of life in today's society, shock of modern sports culture, and the lagging behind of local economic development, the development of traditional culture of 
Shui Nationality has been severely affected, some featured culture is gradually weakening and declining, and the unique traditional customs and folk culture of Shui Nationality are facing the risk of lost, therefore, it is extremely urgent to inherit and spread ethnic culture of Shui Nationality, although the country has taken great efforts to retain and carry forward the traditional culture of minorities, but the task still is a long way to go.

\section{References}

[1] Qu Yijiang, Observe the Influence of Han Chinese Culture towards Shui Nationality from the Spread of Chinese Characters, Study on Chinese Characters, 2011(6): 115-129.

[2] Zhang Xingxiong, Summary of Cultural Study of Shui Nationality in Yunnan, Culture and History Vision (Theory), 2011(2):19-21.

[3] Xioa Yuanping, Characteristics of Shui Festivals, Journal of Kaili University, 2008, 26(5):88.

[4] Gu Xiaoyan, Summary of Shui Nationality's Traditional Sports Culture, Sport Science, 2004(11): 62-64.

[5] Zhang Xingxiong, Gu Xiaoyan, Zhang Dongxiu, Investigation on Shui People Traditional Sports Items in Yunnan Province[J], Journal of Xi'an Institute of Physical Education, 2010(4): 438.

[6] Gu Xiaoyan, Zhang Dongxiu, Survey of transformation of traditional sport culture in regions inhabited by Shui people in China - Research into traditional sport culture in Sandu Shui Minority Autonomous County of Guizhou province, Journal of Wuhan Institute of Physical Education, 2006, (10): 78.

[7] Wen Zhan, The Historical and Realistic Values of Tongzibiao Dart of Northwest Guangxi [J], Journal of PLA Institute of Physical Education, 2009(03): 92-94.

[8] Xun Libo, Cultural Background and Value Research for Gugan Shui Nationality to Create “Swallowing mouth” Dance, Yunnan University, 2010: 1-40.

[9] Xiao Yuanshi, Study on the Living Situation and Developmental Dynamic Mechanism of the Traditional Sports Culture of the Shui Nationality in Yunnan Province, Forward Position, 2010 (2): 197-199. 